\title{
Nicotine Content in Electronic Cigarette Refill Solutions and Its Release in Aerosols
}

\author{
Sharifah Mazrah Sayed Mohamed Zain ${ }^{1 *}{ }^{(1)}$, Sara Khalida Jamal Khair ${ }^{2}$, Nadia Mohamad1, \\ Mohd Fairulnizal Md. Noh ${ }^{3}$, Dinash Aravind Radhakrishnan² \\ ${ }^{1}$ Environmental Health Research Centre, Institute for Medical Research, Ministry of Health Malaysia, Selangor, Malaysia \\ ${ }^{2}$ National Pharmaceutical Regulatory Agency, Ministry of Health Malaysia, Selangor, Malaysia \\ ${ }^{3}$ Nutrition, Metabolic and Cardiovascular Research Centre, Institute for Medical Research, Ministry of Health Malaysia, Selangor, \\ Malaysia \\ Email: *sharifah@imr.gov.my
}

How to cite this paper: Zain, S.M.S.M., Khair, S.K.J., Mohamad, N., Noh, M.F.Md. and Radhakrishnan, D.A. (2019) Nicotine Content in Electronic Cigarette Refill Solutions and Its Release in Aerosols. Journal of Environmental Protection, 10, 1317-1332. https://doi.org/10.4236/jep.2019.1010078

Received: August 9, 2019

Accepted: October 13, 2019

Published: October 16, 2019

Copyright $\odot 2019$ by author(s) and Scientific Research Publishing Inc. This work is licensed under the Creative Commons Attribution International License (CC BY 4.0).

http://creativecommons.org/licenses/by/4.0/

(c) (i) Open Access

\begin{abstract}
Electronic cigarette (EC) is a device that imitates conventional cigarettes, which vaporizes a solution, with or without nicotine. This study evaluates the nicotine levels in EC refill solutions, its release in aerosols and comparison to the amount stated on the label. Seventy-two (72) different EC refill solutions were obtained from local shops in Selangor, Malaysia consisting of 40 nicotine-containing $(3-12 \mathrm{mg})$ and 32 nicotine-free $(0 \mathrm{mg})$ solutions. Aerosols were obtained by using an air tight syringe connected to an EC device to draw aerosol through an XAD-4 sorbent tube that trapped the nicotine. Nicotine in solution and aerosol samples are analyzed using gas chromatography-mass spectrometry equipment. Quantified nicotine in 40 nicotine-containing solutions ranged from $0.224-17.306 \mathrm{mg} / \mathrm{mL}$. Nicotine is detected in 3 of the 32 nicotine-free solutions. Percentage of nicotine released into aerosols from refill solutions varied from $0.54 \%-28.2 \%$. Out of the 40 samples, thirty-two (32) had nicotine content that violated by more than $\pm 10 \%$ from the value on the label. In comparing the labels, 19 samples have $0.3 \%$ - 77\% higher nicotine level and 13 samples have $0.2 \%-96.3 \%$ lower nicotine content. The inconsistency between the labelled and true levels of nicotine content indicates that commercial information may be misleading. The presence of nicotine in the nicotine-free refill solutions and higher nicotine content in aerosols may be addictive and may have negative health effects on users.
\end{abstract}

\section{Keywords}

Electronic Nicotine Delivery Systems, Tobacco Products, Tobacco Industry, Vapers 


\section{Introduction}

An electronic cigarette (EC) is a battery-operated device that emulates a conventional cigarette. The basic operation of EC is by activating the power button and heating elements that vaporize the solution in the cartridge or tank, generating aerosol that is later inhaled by the user [1] [2]. The EC products such as the refill solutions have been widely spread through the global market that can be purchased from almost anywhere, online stores, retail outlets and in shopping malls. The refill solutions availably vary in nicotine amount to nicotine-free with variety of flavors, with or without glycerine (VG) and propylene glycol (PG) [3] [4]. The VG and PG are the most common solvents for nicotine as when they are heated, they form an aerosol that imitates the cigarette smoke [5]. Following the trend, the usage of EC has become well-known in Malaysia. A population study has reported the prevalence of EC users among Malaysian adults is $3.2 \%$ with an estimated number of 602,122 [6]. In the report, $45 \%$ of the 4288 respondents agree that EC is less harmful than tobacco smoking [6]. Another local population survey reported the respondent's perception that only $27 \%(\mathrm{n}=277)$ agree that conventional cigarettes are more harmful than EC while $47 \%$ believe that EC delivers less nicotine than cigarettes [7].

Nicotine has been reported to be highly addictive that can cause acute toxicity at high dose and may suppress the immune system [8]. This has led the policymakers to set related regulation on EC which varies across countries ranging from no regulation to banning them entirely [9]. For countries that have yet established a regulation on EC products, the quality of the products produced is questionable. Lack of manufacturing standards has led to contradictions of nicotine amount in the refill solution with the amount on the label and inconsistencies across the same brand [5] [10] [11] [12]. Furthermore, nicotine was also detected in the EC refill solutions that were labelled as not containing any nicotine [13]. In 2012, American E-Liquid Manufacturing Standards Association (AEMSA) started a voluntary self-regulating standard on the manufacturing of EC cartridges and refill liquids. According to AEMSA, all EC products produced must be within the tolerance level of $\pm 10 \%$ nicotine content in the final product [14].

At the time of publication, a standard on the manufacturing of EC solutions is not available in Malaysia. Therefore, the quality of the EC products offered in the Malaysian market is uncertain by which little is known on the chemical contents including nicotine in EC solutions and aerosols. As nicotine is not a safe chemical, it is important to know the concentration of nicotine that is delivered to the users. Limited studies were conducted in the past regarding nicotine levels in EC and how much is released in aerosols. Information on the likely concentrations of nicotine released in the aerosol is yet to be established. The data from this study may be used by the government to make decisions on policies or laws on EC use and control. This study evaluated the characteristics of different brands and flavors of EC refill solutions available in Malaysia, measured the nicotine content in EC refill solutions and amount released in the aerosols as well 
as comparing the measured nicotine to the value stated on the label.

\section{Methods}

\subsection{Study Design and Setting}

We conducted an experimental study started in January to December 2016. The EC refill solutions were purchased in June 2016 within all ten (10) districts area in Klang valley, Selangor, Malaysia. All samples were analyzed within three months of purchase.

\subsection{Refill Solution}

\subsubsection{Test Samples}

The study team purchased the refill solution samples directly from different local shops and night markets. The refill solutions were bought based on the nicotine content varying from 0 to $12 \mathrm{mg} / \mathrm{mL}$, referring to the label. We bought different flavors and brands of refill solutions consisting of nicotine-free $(0 \mathrm{mg})$ and nicotine-containing solutions $(3-12 \mathrm{mg})$. The selection of the refill solutions was based on popular and best-seller brands as claimed by the local vendors.

\subsubsection{Sample Characteristics}

The characteristics of all refill solution samples were evaluated based on the information of the packaging labels. The amount of nicotine, shelf-life information, levels of PG and VG were extracted from the label. The materials used in the manufacturing of refill solution bottles were observed visually. The $\mathrm{pH}$-indicator strips ( $\mathrm{pH} 0$ - 14) by Merck KGaA (Darmstadt, Germany), a universal indicator are used to rapidly measure the $\mathrm{pH}$ of each refill solution sample. The nicotine in the free form was calculated using the Henderson-Hasselbach equation based on the measured $\mathrm{pH}$ and quantified nicotine [15].

\subsubsection{EC Device and Apparatus}

The EC device was purchased from a local shop, which consisted of an atomizer and solution tank. The characteristics of the atomizer and solution tank used for generating aerosol samples are elaborated in Table 1. To avoid cross contamination and carryover of samples, each of the device part was cleaned using laboratory detergent and sonicated in an ultrasonic bath with solution containing detergent for 30 minutes. The parts were then rinsed and sonicated in tap water for 30 minutes and finally dried in an oven at $60^{\circ} \mathrm{C}$ for 5 minutes.

A $50 \mathrm{~mL}$ Hamilton syringe, 1000 series GASTIGHT, (Cat.no 20707) was bought from Sigma-Aldrich Corporation (Missouri, USA). Sorbent tubes type $\mathrm{XAD}^{\oplus}-4$ in a 40/80 $\mathrm{mg}$ glass tube were used (70 $\mathrm{mm}$ long; $7 \mathrm{~mm}$ outer diameter; 20/40 mesh, glass sealed ends and glass wool separators; Cat.no 226-93; SKC Inc., PA, USA). Two sizes of latex rubber tubing black from SKC Inc. were used, which are type 1/4-inch ID $\times 3 / 8$-inch OD (Cat. No 226-03-004) and type 3/16-inch ID $\times$ 5/16-inch OD (Cat. No 226-03-003). 
Table 1. Characteristics of the EC atomizer and solution tank used for aerosol sampling.

\begin{tabular}{|c|c|c|}
\hline Device part & Atomizer & Solution tank \\
\hline Name & Elfin Mod & Subtank $^{\mathrm{TM}}$ Mini \\
\hline Manufacture & $\begin{array}{l}\text { Shenzen S-Body Electronics } \\
\text { Technology Co., Ltd., Shenzhen, China }\end{array}$ & $\begin{array}{l}\text { Shenzen Kanger Technology Co., Ltd., } \\
\text { Shenzhen, China }\end{array}$ \\
\hline Features & $\begin{array}{l}1 \text { - } 40 \mathrm{~W} ; \\
\text { Resistance } 0.16-2.0 \Omega \text {; } \\
\text { Built-in } 18,500 \text { battery }\end{array}$ & $\begin{array}{l}\text { Atomizer head } 1.2 \Omega \text {; } \\
\text { RBA Plus Base } 0.5 \Omega / 30 \mathrm{~W} \text { coil; } \\
\text { Japanese organic cotton }\end{array}$ \\
\hline Material & $\begin{array}{l}\text { Zinc alloy; } \\
\text { Stainless steel }\end{array}$ & $\begin{array}{l}\text { Stainless steel; } \\
\text { Strengthen pyrex glass }\end{array}$ \\
\hline Size & $65 \times 32 \times 22 \mathrm{~mm}$ & $22 \mathrm{~mm}$ diameter $\times 48 \mathrm{~mm}$ length \\
\hline Capacity & $1400 \mathrm{mAh}$ battery & $4.5 \mathrm{~mL}$ \\
\hline
\end{tabular}

\subsubsection{Aerosol Collection}

At the time of publication, there was no established smoking machine that was designed for the EC sampling. To produce aerosol from the liquid solution, firstly the EC device was activated and then the atomizer heated up the liquid and transformed it into aerosol. In order to provide reproducible and quantitative results, a simple sampling device was adapted from Herrington and Myers (2015) approach using a gas tight syringe connected to a sorbent tube and then to the EC device. In this study, the $50 \mathrm{~mL}$ gas tight syringe was connected to one end of an $\mathrm{XAD}^{\circ}-4$ sorbent tube using a 3/16-inch ID latex tubing. The other end of the sorbent tube was connected to the EC device using the 1/4-inch ID latex tubing (Figure 1). After the refill solution was filled into the solution tank, the EC device was activated (LED light up) to heat the refill solution until aerosol was produced. The EC was observed to light each time the aerosol was drawn through the sorbent tube. The syringe was used to draw $40 \mathrm{~mL}$ of the aerosol from the EC device and in addition to the single puff sample, 13-puff with 4 s/puff separated by 10 seconds intervals between puffs sample was taken in order to mimic a smoking regime corresponding to the average amount of puffs per vaping event [16]. A total of $520 \mathrm{~mL}$ of aerosol was taken from each refill solution and all testing procedures were carried out using the same conditions. Nicotine that was presence in the aerosol was drawn through the sorbent tube and trapped by the front and back sections of the tube. Sorbent tubes were then prepared to be analyzed.

\subsection{Nicotine Analysis in Refill Solution and Aerosol}

\subsubsection{Sample Preparation-Refill Solution}

The refill solution samples were prepared by taking $5 \mu \mathrm{L}$ of sample from the refill solution bottle, and added with $10.0 \mu \mathrm{g} / \mathrm{mL}$ caffeine internal standard solution. The samples were then diluted to $1.5 \mathrm{~mL}$ methanol (1:300 dilution) in $2 \mathrm{~mL}$ vials. The resulting solution was sonicated for 10 minutes prior to analysis.

\subsubsection{Sample Preparation-Aerosol Samples}

The aerosol samples collected using sorbent tubes were prepared by transferring 


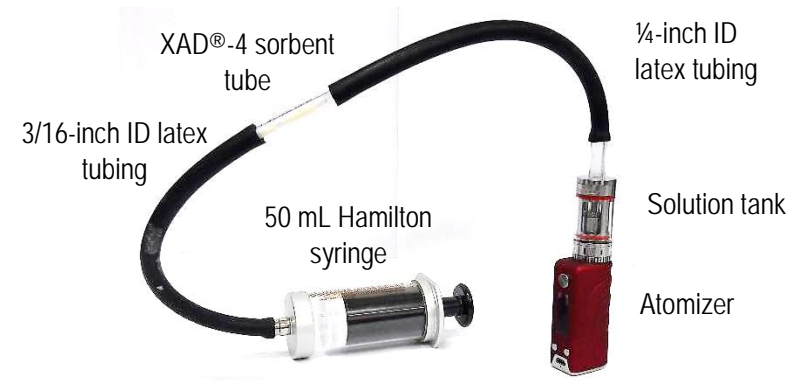

Figure 1. Apparatus set-up for aerosol sampling consists of $50 \mathrm{~mL}$ Hamilton air-tight syringe, latex tubings, $\mathrm{XAD}^{\circledR}-4$ sorbent tube and e-cigarette devices.

the front section $(80 \mathrm{mg}$ ) of the tube into a $2 \mathrm{~mL}$ vial, while the back section (40 $\mathrm{mg}$ ) was placed in a separate vial. A desorbing solution of $0.01 \%$ trimethylamine in ethyl acetate was prepared; $1 \mathrm{~mL}$ of desorbing solution was added into each vial. All vials were placed in an ultrasonic bath for 15 minutes to facilitate desorption. A range of $0.1-0.8 \mathrm{~mL}$ of the resulting solution was pipetted into a vial and added with $10.0 \mu \mathrm{g} / \mathrm{mL}$ of caffeine standard solution (internal standard). Each sample was further diluted with methanol, capped and ready to be analyzed.

\subsubsection{Chemicals}

All analytical standards and solvents used were of an analytical grade. Methanol and ethyl acetate were obtained from Merck \& Company, Inc., (New Jersey, USA). Trimethylamine, $\geq 99 \%$ and (-)-nicotine solution, $1.010 \mathrm{~g} / \mathrm{mL}$ were purchased from Sigma-Aldrich Corporation (Missouri, USA). Caffeine (used as internal standard) is a secondary reference standard that was obtained from the Reference Standard Section of National Pharmaceutical Regulatory Agency Malaysia.

\subsubsection{Analytical Method}

Nicotine in refill solutions and aerosol were analyzed using gas chromatography-mass spectrometer detector (GC-MS, Shimadzu Corporation). The analytical conditions and parameters were described in Table 2. The calibration for refill solution samples was prepared by diluting the (-)-nicotine standard solution $(1.010 \mathrm{~g} / \mathrm{mL}$ ) with methanol to produce concentrations of $1.0 \mu \mathrm{g} / \mathrm{mL}$ (limit of detection), $5.0 \mu \mathrm{g} / \mathrm{mL}$ (limit of quantitation), $10.0 \mu \mathrm{g} / \mathrm{mL}, 20.0 \mu \mathrm{g} / \mathrm{mL}, 25.0$ $\mu \mathrm{g} / \mathrm{mL}$ and $30.0 \mu \mathrm{g} / \mathrm{mL}$. The nicotine working standards were spiked with 10.0 $\mu \mathrm{g} / \mathrm{mL}$ of caffeine standard solution as internal standard. The calibration curve was established by plotting the ratio of peak area (response factor) against the concentration ratio with $\mathrm{R}^{2}=0.9993$. This method has good precision with the percentage relative standard deviation (\% RSD) of $5.4 \%$ and excellent recovery of $99.3 \%( \pm 4.0)$.

The method for the determination of nicotine in the air was based on NIOSH 2551 standard with modification [17]. The calibration curve was constructed by diluting the (-)-nicotine standard solution $(1.010 \mathrm{~g} / \mathrm{mL})$ with methanol to cover 
the range of nicotine concentration from 5.0 to $35 \mu \mathrm{g} / \mathrm{mL}$. The range correspondent to cumulative nicotine levels in aerosol from 0.009 to $2.625 \mathrm{mg}$. The limit of detection is $0.5 \mu \mathrm{g} / \mathrm{mL}$ and the quantitation limit is $1.0 \mu \mathrm{g} / \mathrm{mL}$. This nicotine working standards were spiked with $10.0 \mu \mathrm{g} / \mathrm{mL}$ of caffeine standard solution as internal standard. The calibration curve is established by plotting the ratio of peak area (response factor) against the concentration ratio with $\mathrm{R}^{2}=0.9994$. Quality control samples were analyzed before and after each analysis to ensure that the method was able to produce accurate results. The accuracy of these methods was established during the method validation based on the result of precision, linearity and specificity parameters.

Table 2. Analytical system and parameters used for determination of nicotine refill solutions and aerosol using gas chromatography-mass spectrometry (GC-MS).

\begin{tabular}{|c|c|}
\hline \multicolumn{2}{|l|}{ Analytical equipment } \\
\hline Nicotine in refill solution & $\begin{array}{l}\text { GC-2010 gas chromatograph equipped with QP2010 } \\
\text { ultra mass spectrometer (Shimadzu Corporation) }\end{array}$ \\
\hline Nicotine in aerosol & $\begin{array}{l}\text { GC-2010 gas chromatograph equipped with TQ8040 } \\
\text { mass spectrometer (Shimadzu Corporation) }\end{array}$ \\
\hline Auto sampler/injector & AOC-20s Auto sampler and AOC-20i Auto injector \\
\hline Column & $\begin{array}{l}\text { SH-Rxi-5Sil MS }(30 \mathrm{~m}, 0.25 \mathrm{~mm} \text { ID, } 0.25 \mu \mathrm{m}) \\
\text { (Shimadzu Corporation) }\end{array}$ \\
\hline Injection mode & Split 20:1 \\
\hline Injection temperature & $280^{\circ} \mathrm{C}$ \\
\hline Injection pressure & $200 \mathrm{kP}$ for 1 minute \\
\hline Carrier gas & Helium (Purity 99.999\%), constant flow \\
\hline Flow rate & $1.0 \mathrm{~mL} / \mathrm{min}$ \\
\hline Linear velocity & $37.2 \mathrm{~cm} / \mathrm{sec}$ \\
\hline Oven & $\begin{array}{l}100^{\circ} \mathrm{C} \text { was held for } 1 \text { minute then ramped at rate of } \\
30^{\circ} \mathrm{C} / \mathrm{min} \text { to } 280^{\circ} \mathrm{C} \text {, which was further held for } 4 \\
\text { minutes }\end{array}$ \\
\hline Run time & 11 minutes \\
\hline Solvent delay & 2.5 minutes \\
\hline Quantitation mode & Selected Ion Monitoring (SIM) \\
\hline Source temperature & $200^{\circ} \mathrm{C}$ \\
\hline Interface temperature & $280^{\circ} \mathrm{C}$ \\
\hline Acquisition mode & $\begin{array}{l}\mathrm{m} / \mathrm{z} 50 \text { - 500, confirmed with the NIST14 specteral } \\
\text { library }\end{array}$ \\
\hline Target ion for nicotine in refill solution & $\begin{array}{l}\mathrm{m} / \mathrm{z} 84 \text { (nicotine) and reerence ions } \mathrm{m} / \mathrm{z} 133 \text { and } \\
\mathrm{m} / \mathrm{z} 161\end{array}$ \\
\hline Target ion for nicotine in aerosol solution & $\begin{array}{l}\mathrm{m} / \mathrm{z} 84 \text { (nicotine) and reerence ions } \mathrm{m} / \mathrm{z} 133 \text { and } \\
\mathrm{m} / \mathrm{z} 162\end{array}$ \\
\hline Target ion for IS & $\begin{array}{l}\mathrm{m} / \mathrm{z} 194 \text { (caffeine) and reference ions } \mathrm{m} / \mathrm{z} 109 \text { and } \\
\mathrm{m} / \mathrm{z} 55\end{array}$ \\
\hline Ion tolerance in SIM mode & $30 \%$ \\
\hline
\end{tabular}




\subsection{Ethical Consideration}

This study protocol was approved by the Ministry of Health Research and Ethics Committee, Ministry of Health Malaysia with exemption as no ethical issues involved.

\section{Results}

\subsection{Sample Characteristics}

Seventy-two (72) EC refill solutions were analyzed through different flavors from more than 60 brands. Samples consisted of 32 nicotine-free $(0 \mathrm{mg})$ and 40 nicotine-containing refill solutions (3 - $12 \mathrm{mg}$ ). The characteristics of EC samples are presented in Table 3. In most samples (75\%), the amount of nicotine, $\mathrm{PG}$, and VG were declared in the ingredients. Sweetener, artificial food flavoring, food coloring, and warning statement are also stated in general. The supplier's information or address was not mentioned in any of the samples, however, most samples showed the supplier's website addresses in social media. The shelf life information and country of manufacture are the least mentioned on the label.

Based on the labels of 40 nicotine-containing refill samples, the most common amount of nicotine is $6 \mathrm{mg} / \mathrm{mL}$ (65\%). Of 72 samples, 67 (93\%) did not state the shelf life information of the product. The amount of PG in the nicotine-containing refill solutions is slightly higher $(30 \%-60 \%)$ compared to the amount in the nicotine-free refill solutions $(0 \%-60 \%)$. However, the VG content in the nicotine-containing solutions is lower (33\% to 70\%) compared to its amount in the nicotine-free solutions ( $40 \%$ to $100 \%)$. The average amounts of PG and VG in the nicotine-containing samples are found to be equal, $50 \% \pm 7 \%$ and $50 \% \pm 8 \%$, respectively. However, the average amount of VG is much higher $(72 \% \pm 23 \%)$ compared to the amount of PG $(27 \% \pm 23 \%)$ in the nicotine-free samples. A total of 18 out of $72(25 \%)$ refill samples have no information on the compositions of both PG and VG. In terms of warning statement, these are among the stated, "Keep out of reach of children and animal"; "Not for use by pregnant women and under 18 years of age", "18+"; "Shake before use" and "Keep in cool place"; "Nicotine can be poisonous"; "Do not drink" and "Stop smoking". Most of the refill bottle packaging is made of plastic (52 out of 72, $79 \%)$ and the rest are manufactured in glass. The capacity of the free-nicotine solution bottles is slightly smaller $(20-40 \mathrm{~mL})$ compared to the nicotine-containing solution bottles $(30-55 \mathrm{~mL})$. The most common (85\%) volume of the refill solution bottle is $30 \mathrm{~mL}$. The average of $\mathrm{pH}$ value is lower in the nicotine-free refill solutions, $\mathrm{pH} 4.5 \pm 0.8$ and slightly increased for the nicotine-containing refill solutions; $\mathrm{pH} 5.2 \pm 0.7$ (6 mg/mL nicotine); $\mathrm{pH} 5.6 \pm 0.5$ (9 $\mathrm{mg} / \mathrm{mL}$ nicotine $)$ and $\mathrm{pH} 5.8 \pm 0.8(12 \mathrm{mg} / \mathrm{mL}$ nicotine $)$.

\subsection{Nicotine in Refill Solutions}

The measured nicotine is inconsistent throughout different flavors and brands of samples. The quantified nicotine in 40 nicotine-containing solutions ranged 
Table 3. Characteristics of refill solution samples including the bottle capacity, percentage of polypropylene glycol, vegetable glycerin, bottle material and $\mathrm{pH}$ values, as well as the levels of nicotine analyzed in refill solutions, relative difference between the quantified and label, free nicotine content and levels of nicotine released to aerosol.

\begin{tabular}{|c|c|c|c|c|c|c|c|c|c|c|c|c|}
\hline No & Sample Code & $\begin{array}{c}\text { Bottle } \\
\text { capacity } \\
(\mathrm{mL})\end{array}$ & PG (\%) & VG (\%) & $\begin{array}{c}\text { Bottle } \\
\text { material, } \\
\text { Shelf life }\end{array}$ & $\mathrm{pH}$ & $\begin{array}{l}\text { Labelled } \\
\text { nicotine } \\
(\mathrm{mg} / \mathrm{mL})\end{array}$ & $\begin{array}{l}\text { Quantified } \\
\text { nicotine in } \\
\text { solution } \\
(\mathrm{mg} / \mathrm{mL})\end{array}$ & $\begin{array}{c}\text { Relative } \\
\text { difference } \\
(\%)\end{array}$ & $\begin{array}{c}\text { Free } \\
\text { nicotine } \\
(\mathrm{mg} / \mathrm{mL})\end{array}$ & $\begin{array}{c}\text { Quantified } \\
\text { nicotine in } \\
\text { aerosol } \\
\text { (mg/mL) } \\
\text { (13-puffs) }\end{array}$ & $\begin{array}{c}\text { Nicotine } \\
\text { released to } \\
\text { aerosol from } \\
\text { solution (\%) }\end{array}$ \\
\hline \multicolumn{13}{|c|}{ 1) Nicotine-containing refill solutions } \\
\hline 1 & EN01 & 30 & 40 & 60 & $\mathrm{P}, \mathrm{ns}$ & 5 & 6 & 0.224 & -96.3 & $<0.001$ & 0.036 & 16.1 \\
\hline 2 & EN02 & 30 & 50 & 60 & $\mathrm{P}, \mathrm{ns}$ & 5 & 6 & 0.775 & -87.1 & 0.001 & 0.060 & 7.7 \\
\hline 3 & EN03 & 30 & 50 & 50 & $\mathrm{P}, \mathrm{ns}$ & 4 & 6 & 0.855 & -85.8 & $<0.001$ & 0.045 & 5.3 \\
\hline 4 & ES04 & 30 & 50 & 50 & $\mathrm{P}, \mathrm{ns}$ & 5 & 6 & 2.588 & -56.9 & 0.002 & 0.138 & 5.3 \\
\hline 5 & EN05 & 30 & ns & ns & $\mathrm{P}, \mathrm{ns}$ & 5 & 6 & 2.140 & -64.3 & 0.002 & 0.123 & 5.7 \\
\hline 6 & EN06 & 30 & 47 & 53 & G, ns & 6 & 7.5 & 3.462 & -53.8 & 0.033 & 0.291 & 8.4 \\
\hline 7 & ES07 & 30 & 50 & 50 & $\mathrm{P}, \mathrm{ns}$ & 6 & 6 & 3.707 & -38.2 & 0.035 & 0.527 & 14.2 \\
\hline 8 & ES08 & 30 & 50 & 50 & $\mathrm{P}, \mathrm{ns}$ & 6 & 6 & 3.740 & -37.7 & 0.035 & 0.373 & 10.0 \\
\hline 9 & ES09 & 30 & 50 & 50 & P, 2018 & 6 & 6 & 3.754 & -37.4 & 0.036 & 0.140 & 3.7 \\
\hline 10 & ES10 & 30 & 50 & 50 & $\mathrm{P}, \mathrm{ns}$ & 6 & 6 & 3.791 & -36.8 & 0.036 & 0.311 & 8.2 \\
\hline 11 & ES11 & 30 & 50 & 50 & $\mathrm{P}, \mathrm{ns}$ & 6 & 6 & 3.797 & -36.7 & 0.036 & 0.040 & 1.1 \\
\hline 12 & EN12 & 35 & $\mathrm{~ns}$ & ns & $\mathrm{P}, \mathrm{ns}$ & 5 & 6 & 3.969 & -33.9 & 0.004 & 0.376 & 9.5 \\
\hline 13 & ES13 & 30 & 50 & 50 & $\mathrm{P}, \mathrm{ns}$ & 4 & 6 & 4.092 & -31.8 & $<0.001$ & 0.309 & 7.6 \\
\hline 14 & EN14 & 30 & 30 & 70 & $\mathrm{~g}, \mathrm{~ns}$ & 5 & 6 & 4.264 & -28.9 & 0.004 & 0.238 & 5.6 \\
\hline 15 & ES15 & 30 & 50 & 50 & $\mathrm{P}, \mathrm{ns}$ & 5 & 6 & 4.517 & -24.7 & 0.004 & 0.497 & 11.0 \\
\hline 16 & ES16 & 30 & 50 & 50 & $\mathrm{G}$, ns & 5 & 6 & 4.525 & -24.6 & 0.004 & 0.230 & 5.1 \\
\hline 17 & ES17 & 30 & $\mathrm{~ns}$ & $\mathrm{~ns}$ & $\mathrm{P}, \mathrm{ns}$ & 6 & 6 & 4.560 & -24.0 & 0.043 & 0.457 & 10.0 \\
\hline 18 & EN18 & 30 & $\mathrm{~ns}$ & ns & $\mathrm{P}, \mathrm{ns}$ & 5 & 5 & 4.091 & -18.2 & 0.004 & 0.363 & 8.9 \\
\hline 19 & ES19 & 30 & 50 & 50 & $\mathrm{P}, \mathrm{ns}$ & 6 & 6 & 5.039 & -16.0 & 0.048 & 0.463 & 9.2 \\
\hline 20 & EN20 & 30 & ns & ns & $\mathrm{P}, \mathrm{ns}$ & 6 & 6 & 5.428 & -9.5 & 0.051 & 0.640 & 11.8 \\
\hline 21 & EN21 & 55 & Low & High & $\mathrm{P}, \mathrm{ns}$ & 5 & 3 & 2.853 & -4.9 & 0.003 & 0.169 & 5.9 \\
\hline 22 & EN22 & 30 & 60 & 40 & $\mathrm{P}, \mathrm{ns}$ & 4 & 6 & 5.875 & -2.1 & 0.001 & 0.640 & 10.9 \\
\hline 23 & EN23 & 30 & 50 & 50 & $\mathrm{P}, \mathrm{ns}$ & 4 & 6 & 5.989 & -0.2 & 0.001 & 0.445 & 7.4 \\
\hline 24 & ES24 & 30 & 40 & 60 & $\mathrm{G}, \mathrm{ns}$ & 6 & 12 & 12.033 & 0.3 & 0.114 & 0.166 & 1.4 \\
\hline 25 & ES25 & 50 & $\mathrm{~ns}$ & ns & $\mathrm{G}, \mathrm{ns}$ & 5 & 9 & 9.129 & 1.4 & 0.009 & 0.702 & 7.7 \\
\hline 26 & ES26 & 55 & 50 & 50 & $\mathrm{P}, \mathrm{ns}$ & 5 & 6 & 6.233 & 3.9 & 0.006 & 0.518 & 8.3 \\
\hline 27 & ES27 & 30 & 60 & 40 & $\mathrm{P}, \mathrm{ns}$ & 5 & 6 & 6.573 & 9.6 & 0.006 & 0.535 & 8.1 \\
\hline 28 & ES28 & 30 & 50 & 50 & $\mathrm{P}, \mathrm{ns}$ & 6 & 9 & 10.777 & 19.7 & 0.102 & 0.762 & 7.1 \\
\hline 29 & ES29 & 30 & 60 & 40 & $\mathrm{G}, \mathrm{ns}$ & 5 & 12 & 14.880 & 24.0 & 0.014 & 1.165 & 7.8 \\
\hline 30 & ES30 & 30 & ns & ns & $\mathrm{G}, \mathrm{ns}$ & 6 & 12 & 14.989 & 24.9 & 0.142 & 1.167 & 7.8 \\
\hline 31 & ES31 & 30 & 50 & 50 & $\mathrm{G}, \mathrm{ns}$ & 6 & 9 & 11.356 & 26.2 & 0.107 & 1.056 & 9.3 \\
\hline 32 & ES32 & 30 & ns & ns & $\mathrm{P}, \mathrm{ns}$ & 5 & 6 & 7.580 & 26.3 & 0.007 & 0.100 & 1.3 \\
\hline 33 & ES33 & 30 & ns & 33 & $\mathrm{P}, \mathrm{ns}$ & 6 & 12 & 15.292 & 27.4 & 0.145 & 1.563 & 10.2 \\
\hline 34 & ES34 & 30 & $\mathrm{~ns}$ & 33 & $\mathrm{P}, \mathrm{ns}$ & 5 & 9 & 11.570 & 28.6 & 0.011 & 0.973 & 8.4 \\
\hline
\end{tabular}




\section{Continued}

\begin{tabular}{|c|c|c|c|c|c|c|c|c|c|c|c|c|}
\hline 35 & ES35 & 30 & $\mathrm{~ns}$ & ns & $\mathrm{P}, \mathrm{ns}$ & 5 & 12 & 15.544 & 29.5 & 0.015 & 1.735 & 11.2 \\
\hline 36 & ES36 & 30 & 60 & 40 & $\mathrm{P}, \mathrm{ns}$ & 5 & 6 & 7.791 & 29.9 & 0.007 & 0.641 & 8.2 \\
\hline 37 & EN37 & 30 & ns & ns & $\mathrm{P}, \mathrm{ns}$ & 5 & 6 & 8.573 & 42.9 & 0.008 & 0.495 & 5.8 \\
\hline 38 & EN38 & 30 & 50 & 50 & $\mathrm{P}, \mathrm{ns}$ & 7 & 12 & 17.306 & 44.2 & 1.509 & 1.528 & 8.8 \\
\hline 39 & ES39 & 30 & 50 & 50 & $\mathrm{G}, \mathrm{ns}$ & 6 & 9 & 13.614 & 51.3 & 0.129 & 0.890 & 6.5 \\
\hline 40 & ES40 & 30 & 40 & 60 & $\mathrm{P}, \mathrm{ns}$ & 5 & 6 & 10.617 & 77.0 & 0.010 & 0.049 & 0.5 \\
\hline \multicolumn{13}{|c|}{ 2) Nicotine-free refill solutions } \\
\hline 1 & FS01 & 30 & 50 & 50 & $\mathrm{P}, \mathrm{ns}$ & 5 & 0 & 4.783 & - & 0.005 & 1.349 & 28.2 \\
\hline 2 & FN02 & 30 & ns & ns & $\mathrm{P}, \mathrm{ns}$ & 5 & 0 & 1.269 & - & 0.001 & 0.099 & 7.8 \\
\hline 3 & FS03 & 30 & ns & ns & G, ns & 4 & 0 & 2.093 & - & $<0.000$ & 0.088 & 4.2 \\
\hline 4 & FS04 & 30 & 60 & 40 & $\mathrm{P}, \mathrm{ns}$ & 5 & 0 & ND & - & ND & - & - \\
\hline 5 & FS05 & 30 & ns & ns & $\mathrm{P}, \mathrm{ns}$ & 5 & 0 & ND & - & ND & - & - \\
\hline 6 & FS06 & 30 & $\mathrm{~ns}$ & ns & $\mathrm{P}, \mathrm{ns}$ & 5 & 0 & ND & - & ND & - & - \\
\hline 7 & FN07 & 30 & ns & ns & $\mathrm{P}, \mathrm{ns}$ & 5 & 0 & ND & - & ND & - & - \\
\hline 8 & FN08 & 30 & 0 & 100 & $\mathrm{P}, \mathrm{ns}$ & 5 & 0 & ND & - & ND & - & - \\
\hline 9 & FS09 & 30 & 33.33 & 66.67 & $\mathrm{P}, \mathrm{ns}$ & 4 & 0 & ND & - & ND & - & - \\
\hline 10 & FS10 & 30 & 33.33 & 66.67 & $\mathrm{P}, \mathrm{ns}$ & 5 & 0 & ND & - & ND & - & - \\
\hline 11 & FN11 & 30 & 50 & 50 & $\mathrm{P}, \mathrm{ns}$ & 4 & 0 & ND & - & ND & - & - \\
\hline 12 & FN12 & 30 & ns & ns & $\mathrm{P}, \mathrm{ns}$ & 4 & 0 & ND & - & ND & - & - \\
\hline 13 & FS13 & 30 & 60 & 40 & $\mathrm{P}, \mathrm{ns}$ & 4 & 0 & ND & - & ND & - & - \\
\hline 14 & FS14 & 40 & 0 & 100 & $\mathrm{P}, \mathrm{ns}$ & 5 & 0 & ND & - & ND & - & - \\
\hline 15 & FN15 & 20 & 10 & 90 & $\mathrm{P}, \mathrm{ns}$ & 5 & 0 & ND & - & ND & - & - \\
\hline 16 & FN16 & 20 & 10 & 90 & $\mathrm{P}, \mathrm{ns}$ & 4 & 0 & ND & - & ND & - & - \\
\hline 17 & FS17 & 30 & 20 & 80 & G, 5 July 2017 & 4 & 0 & ND & - & ND & - & - \\
\hline 18 & FS18 & 30 & 20 & 80 & G, 15 June 2017 & 4 & 0 & ND & - & ND & - & - \\
\hline 19 & FN19 & 30 & 0 & 100 & $\mathrm{P}, \mathrm{ns}$ & 4 & 0 & ND & - & ND & - & - \\
\hline 20 & FN20 & 30 & 0 & 100 & $\mathrm{P}, \mathrm{ns}$ & 5 & 0 & ND & - & ND & - & - \\
\hline 21 & FS21 & 30 & 0 & 100 & $\mathrm{P}, \mathrm{ns}$ & 5 & 0 & ND & - & ND & - & - \\
\hline 22 & FS22 & 30 & 0 & 100 & $\mathrm{P}, \mathrm{ns}$ & 4 & 0 & ND & - & ND & - & - \\
\hline 23 & FN23 & 32 & 50 & 50 & $\mathrm{P}, \mathrm{ns}$ & 4 & 0 & ND & - & ND & - & - \\
\hline 24 & FN24 & 32 & 50 & 50 & $\mathrm{P}, \mathrm{ns}$ & 4 & 0 & ND & - & ND & - & - \\
\hline 25 & FS25 & 30 & 50 & 50 & $\mathrm{G}$, ns & 4 & 0 & ND & - & ND & - & - \\
\hline 26 & FS26 & 30 & ns & ns & $\mathrm{P}, \mathrm{ns}$ & 4 & 0 & ND & - & ND & - & - \\
\hline 27 & FS27 & 20 & 10 & 90 & $\mathrm{P}, \mathrm{ns}$ & 5 & 0 & ND & - & ND & - & - \\
\hline 28 & FS28 & 20 & 10 & 90 & $\mathrm{P}, \mathrm{ns}$ & 4 & 0 & ND & - & ND & - & - \\
\hline 29 & FS29 & 30 & ns & 50 & $\mathrm{G}, \mathrm{ns}$ & 4 & 0 & ND & - & ND & - & - \\
\hline 30 & FS30 & 30 & 50 & 50 & G, June 2019 & 4 & 0 & ND & - & ND & - & - \\
\hline 31 & FS31 & 30 & 50 & 50 & P, 2018 & 5 & 0 & ND & - & ND & - & - \\
\hline 32 & FN32 & 30 & ns & ns & $\mathrm{P}, \mathrm{ns}$ & 5 & 0 & ND & - & ND & - & - \\
\hline
\end{tabular}

$\mathrm{ND}=$ not detected $\mathrm{NS}=$ not stated $\mathrm{P}=$ plastic $\mathrm{G}=$ glass $\mathrm{PG}=$ propylene glycol $\mathrm{VG}=$ vegetable glycerine. 
from $0.224 \mathrm{mg} / \mathrm{mL}$ to $17.306 \mathrm{mg} / \mathrm{mL}$ (Table 3). The average nicotine measured was $6.947 \pm 4.605 \mathrm{mg} / \mathrm{mL}$. Nicotine was detected in three (3) out of 32 nicotine-free samples, ranging between 1.269 and $4.783 \mathrm{mg} / \mathrm{mL}$. The nicotine in a free form was calculated for 43 solutions that were identified to contain nicotine. The amount ranged was within $<0.001$ to $1.509 \mathrm{mg} / \mathrm{mL}$ with a trend of increasing free-base nicotine content as the quantified nicotine increased. About half of the samples, $53 \%$ ( 23 of 43 ) had free form nicotine concentration less than 0.010 $\mathrm{mg} / \mathrm{mL}$ while $7 \%$ (3 of 43 ) showed negligible amount of free-base nicotine level of $<0.001 \mathrm{mg} / \mathrm{mL}$.

\subsection{Nicotine in Aerosols}

Aerosol was visibly produced during the 13 puffs taken from each refill solutions tested. Nicotine in aerosols was detected in 43 samples, including in three samples from nicotine-free solutions that were confirmed to contain nicotine (Table $3)$. Nicotine in aerosols that were released from the nicotine-containing solutions varied from $0.036 \mathrm{mg} / \mathrm{mL}$ to $1.735 \mathrm{mg} / \mathrm{mL}$ with an average of $0.535 \pm 0.452$ $\mathrm{mg} / \mathrm{mL}$. The percentage of nicotine released from the refill solutions into the aerosol was between $0.5 \%$ and $28.2 \%$ with an average of $7.9 \% \pm 4.5 \%$. The highest nicotine released into the aerosol occurred in a nicotine-free solution sample, FS01 that was supposed to not contain any nicotine.

\subsection{Comparison of Nicotine Content}

Thirty-two (32) of the 40 nicotine-refill solutions have nicotine content that violated by more than $\pm 10 \%$ of the values stated on the packaging, which is the tolerance level set by AEMSA in their standards [14]. Seventeen (17) nicotine-containing solutions out of 40 samples were identified to have nicotine content higher than what was claimed, ranging from $0.3 \%$ to $77 \%$ higher (Table 3). The other twenty-three (23) solutions showed lower nicotine amount than what was written on the label, ranging between $0.2 \%$ and $96.3 \%$ lower. Overall, the trend of the average differences (\%) of nicotine content compared to the label was $9.6 \%$ lower.

\section{Discussion}

The overall characteristics of EC refill solutions were assessed from the label and physical observation in general, and did not emphasize on specific manufacturers or brands. Nicotine levels in EC varied and were not uniform across the products. The free form of nicotine was relatively low for most of the samples (53\%) with value less than $0.010 \mathrm{mg} / \mathrm{mL}$. Generally, the amount of nicotine released into the aerosol is small at an average of $7.9 \% \pm 4.5 \%$ of the quantified nicotine in the solution. In total, the majority of the nicotine-containing refill solutions ( $80 \%$ ) had nicotine measured contradicting by more than $\pm 10 \%$ from the value written on the label. The differences of values ranging from as low as $-96.3 \%$ to as high as $77 \%$ on average are lower than what is stated on the packaging. 
Generally, the most common type (65\%) of the EC bottle is labelled as 6 $\mathrm{mg} / \mathrm{mL}$ nicotine in $30 \mathrm{~mL}$ volume in a low-density plastic bottle. Overall, the trend of PG and VG content was different in both nicotine-containing and nicotine-free solutions. The concentrations of PG and VG are equivalent in the nicotine-containing samples, however, the VG is higher with an average of $72 \% \pm$ $23 \%$ in the nicotine-free samples. We observed that the EC refill solutions have similar pattern across the samples with lack of important information, such as the manufacturer's information, shelf-life and compositions of the PG and VG. The least information given on the packaging was the name, volume, nicotine level and list of ingredients. More than $90 \%$ of the samples did not declare the life span of the sample. Missing information on the concentrations of nicotine, PG and VG of EC products are also reported in other studies [3] [18]. The low-quality labeling of the EC might be due to the lack of manufacturing standards, monitoring and inspection on the making of the products. The absence of regulation on the EC industry might expose it to an illegal production of EC resulting in poor labeling information. There are possibilities that the sellers produced the solutions at their personal residence or might have made it for do-it-yourself (DIY) purposes. A study found refill solution samples that were intended for DIY are in high excess of nicotine [18]. The label on the bottle is important for the EC users to get important input before using it especially the nicotine amount and the expiry date. Using the EC products beyond its shelf-life might cause negative health effects to the users.

Overall, the varied amount of nicotine was quantified in 40 refill solutions labeled as containing $3-12 \mathrm{mg} / \mathrm{mL}$ nicotine. Nicotine appeared to exist in 3 of 32 refill solutions that were labeled as $0 \mathrm{mg} / \mathrm{mL}$ nicotine. There were a few studies reporting on the nicotine amount measured in EC refill solutions as shown in Table 4. Other research showed higher range of nicotine-containing refill solutions that were measured ranging from $0-36 \mathrm{mg} / \mathrm{mL}$ compared to the samples engaged in this study, ranging from $0-12 \mathrm{mg} / \mathrm{mL}$. The basis on the selection of samples varied between the studies depending on the popularity of samples and the preferred amount of nicotine to be evaluated. Similar to several studies, nicotine was also detected in the nicotine-free refill solutions [10] [18]. However, in contrast, there is a report showing that nicotine was not detected in 4 of 12 nicotine-containing refill solutions [19].

The highest quantified nicotine was in sample EN38 $(17 \mathrm{mg} / \mathrm{mL})$ which also recorded the highest $\mathrm{pH}$ value (7) compared to other samples. The results showed that the $\mathrm{pH}$ values correlated with the quantified nicotine concentration. This paper showed similar trend of $\mathrm{pH}$ values like other studies, where the $\mathrm{pH}$ of EC refill solutions is largely driven by the concentration of nicotine [20]. In general, higher nicotine content yielded higher $\mathrm{pH}$ values due to the inherent alkalinity of nicotine and resulted in higher free-base nicotine level. The nicotine-free and lower nicotine content of refill solutions are slightly acidic possibly due to the absence of nicotine and the presence of weakly acidic substance from the flavor additives [20]. The percentage of nicotine in the free base form that 
Table 4. Other studies conducted regarding nicotine content in EC refill solutions and aerosols, the percentage difference from the label and analytical method used.

\begin{tabular}{|c|c|c|c|c|c|c|}
\hline Reference & $\begin{array}{l}\text { Analytical } \\
\text { equipment }\end{array}$ & Matrix & Units & $\begin{array}{l}\text { Labeled } \\
\text { nicotine }\end{array}$ & $\begin{array}{l}\text { Quantified } \\
\text { nicotine }\end{array}$ & $\begin{array}{l}\text { Difference } \\
\text { with label }\end{array}$ \\
\hline \multirow[b]{2}{*}{ This study 2018} & \multirow[b]{2}{*}{ GC-MS } & Refill solution & $\mathrm{mg} / \mathrm{mL}$ & \multirow[b]{2}{*}{$0-12$} & $0.2-17.0$ & $-96 \%$ to $83 \%$ \\
\hline & & Aerosol & $\mathrm{mg} / \mathrm{mL}$ (13-puff) & & $0.04-1.74$ & NA \\
\hline Joseph, et al. 2015 & GC-MS/MS & Refill solution & $\mathrm{mg} / \mathrm{g}$ & $0-24$ & $3.3-20.5$ & $-45.0 \%$ to $3.8 \%$ \\
\hline Davis et al., 2014 & HP-LC & Refill solution & $\mathrm{mg} / \mathrm{mL}$ & $0-24$ & $5.6-34.4$ & $-12.9 \%$ to $89.7 \%$ \\
\hline Cameron et al. 2014 & LC-MS/MS & Refill solution & $\mathrm{mg} / \mathrm{mL}$ & $6-36$ & $8.5-22.2$ & $-66 \%$ to $42 \%$ \\
\hline \multirow{2}{*}{ Goniewicz et al. 2014} & \multirow{2}{*}{ GC-TSD } & Refill solution & $\mathrm{mg}$ & \multirow{2}{*}{$0-24$} & $0-25$ & $-75 \%$ to $28 \%$ \\
\hline & & Aerosol & $\mathrm{mg} / 150$-puff & & $0.3-8.7$ & NA \\
\hline Etter et al. 2013 & UHPLC-DAD, GC-FID, GC-MS & Refill solution & $\mathrm{mg} / \mathrm{mL}$ & $6-24$ & ND -29.0 & $-15 \%$ to $21 \%$ \\
\hline \multirow{2}{*}{ Trehy et al. 2011} & \multirow{2}{*}{ HPLC-DAD } & Refill solution & $\mathrm{mg} / \mathrm{mL}$ & \multirow{2}{*}{$0-24$} & $0-25.6$ & $-100 \%$ to $100 \%$ \\
\hline & & Aerosol & $\mu \mathrm{g} / 100 \mathrm{~mL}$ puff & & $0-43.2$ & NA \\
\hline
\end{tabular}

GC-MS, gas chromatography coupled with mass spectrometry; GC-MS/MS, gas chromatography coupled with triple quadrupole mass spectrometer; HP-LC, high performance liquid chromatography; LC-MS/MS, liquid chromatography coupled with triple quadrupole mass spectrometer; GC-TSD, gas chromatography coupled with thermionic specific detector; UHPLC-DAD, ultra-high performance liquid chromatography coupled with diode array detector; GC-FID, gas chromatography coupled with flame ionization detector; ND, not detected; HPLC-DAD, high performance liquid chromatography coupled with diode array detector; NA, not applicable

was calculated in this study ranged from $0.01 \%-8.72 \%$. The free or un-protonated form of nicotine is more readily absorbed by the EC user than the protonated forms, accumulating the degree of nicotine inhaled by the user [21]. However, these values are relatively small as compared to another study, $60 \%-90 \%$ [20]. The major difference in the results of free-nicotine percentage between this study and the study by Joseph et al. [20] is may be due to the different approaches in measuring the $\mathrm{pH}$. This study used rapid method to measure the $\mathrm{pH}$ using strip indicator that might have underestimated the $\mathrm{pH}$ values resulting in the calculated free nicotine content lower than the actual. EC users taking solutions at higher nicotine content might have absorbed higher amount of free-nicotine when the aerosol was inhaled.

Until the analysis was conducted, there is no established information available regarding the likelihood of nicotine released in the EC aerosol. The analysis of aerosol involves the generation of the aerosol from EC device. Several chemistry studies had implemented different instrumentations to generate the aerosol from EC. These include the Palaczbot smoking machine [5], laboratory-built device [10] [22] [23] and using syringe [24]. Our study shows that the simple sampling device using an air tight syringe was able to successfully draw EC aerosol into a sorbent tube and provide measurable levels of nicotine from $520 \mathrm{~mL}$ (13-puff). The percentage of nicotine in the aerosols, generated from the solutions is between $0.5 \%(0.036 \mathrm{mg} / \mathrm{mL})$ and $28.2 \%(1.735 \mathrm{mg} / \mathrm{mL})$. Our study reported similar results with another study that showed low nicotine delivery in aerosol between 0 and $0.0432 \mathrm{mg} / 100 \mathrm{~mL}$ puff [10] (Table 4). However, in contrary to a study by Goniewicz et al. [11], high nicotine released in the aerosols between 
$21 \%$ and $85 \%$ is reported. In our study, $520 \mathrm{~mL}$ (13-puff) of aerosols is taken while study [11] reported to sample of more than 20 times of volume, $10.5 \mathrm{~L}$ (150-puff). The amount of nicotine vaporized into aerosol possibly has high correlation to the amount of aerosol volume sampled. We implemented the human use topography (puffs) by [16] in our sampling technique as it determines the actual levels of user exposure to nicotine. The usage of rubber tubing in the apparatus set-up of aerosol sampling might have absorbed a portion of nicotine present in the aerosols. This was likely partly the reason for lower nicotine values quantified in the aerosol than the actual [10]. This finding might indicate that following a puff, nicotine in aerosol is delivered into the user's mouth and lungs by inhalation which the level accumulated is parallel to the amount of puff.

This study reported discrepancies of nicotine concentrations in the refill solutions as compared to the labels on the packaging. Majority of our samples (80\%) have nicotine content which differs by more than $\pm 10 \%$ the tolerance level set by AEMSA in their standard [14]. In general, most nicotine contents are lower than the labeled values, with many being $20 \%$ and lower. Lower amount of nicotine was found from 23 solutions labeled as $6-7.5 \mathrm{mg} / \mathrm{mL}$ nicotine. Meanwhile, higher amount of nicotine originated from $6-12 \mathrm{mg} / \mathrm{mL}$ labeled nicotine samples. It is observed that the higher amount of nicotine has higher possibility to produce bigger difference of nicotine level to what is claimed. Similar findings of contradictions between label and true value were also found in other studies (Table 4). These studies reported significantly lower amount of nicotine than the value on the bottle. This was supported by other researchers [5] [12] [19] which the majority of the refill solutions contained lower nicotine than the manufacturer's information. Different trends were reported in other studies, showing higher values of nicotine in most of the EC refill solutions [10] [18]. The deviation between the nicotine true levels and what were claimed was probably due to the absence of good manufacturing practice, inspection and monitoring as well as unregulated. The EC industry was not bound to any standards or procedure therefore it probably can be prepared as DIY products or based on customer's request. The solutions accurate labeling of nicotine content on EC products is essential as nicotine is both addictive [25] and toxic [26]. The improper labeling might raise potential nicotine overexposure.

The following limitations are acknowledged when interpreting the study results. The study consisted of samples within one state in Malaysia and relied on the information from the sellers which the samples were purchased. Online samples were not included. There was a lack of standardization in methodologies for aerosol generation used for EC analysis. The aerosol sampling method implemented in this study was manually handled that might have resulted in the loss of samples, inconsistencies and accuracy and recovery analysis for aerosol samples were not performed. Despite the limitations, the sample size was adequate to give valid results and supported by many studies. 


\section{Conclusion}

In conclusion, EC refill solutions were inconsistently matched with the label specification with poor information on the label indicating that significant labeling issues were found to exist. EC users should be given reliable information on nicotine content and important information, such as the shelf-life of the products. The greatest concern was the presence of nicotine in the refill solutions labeled to contain no nicotine as it might cause addictive effects to EC users that only take $0 \mathrm{mg} / \mathrm{mL}$ of EC. Higher amount of nicotine than what is claimed might lead to misconception among users who believe EC delivers less nicotine compared to conventional smoking. The deviation of nicotine values showed lack of integrity in manufacturing the EC products and there was a need to establish guidelines to improve the reliability of production for EC devices and solutions.

\section{Acknowledgements}

The authors would like to gratefully acknowledge the financial support from the Ministry of Health Malaysia (grant number NMRR-16-164-28981) and to the Director General of Health Malaysia for the permission to publish. We would like to extend our sincere gratitude to the Environmental Health Research Centre, Institute for Medical Research (IMR), Malaysia and National Pharmaceutical Regulatory Agency Malaysia, who gave us permission to use all the required equipment and necessary materials to complete the task. We thank Dorothy L. Southern for providing scientific advice and critically reviewing the manuscript.

\section{Conflicts of Interest}

The authors declare no conflicts of interest regarding the publication of this paper.

\section{References}

[1] Trtchounian, A. and Talbot, P. (2010) Electronic Nicotine Delivery Systems: Is There a Need for Regulations? Tobacco Control, 20, 47-52. https://doi.org/10.1136/tc.2010.037259

[2] Brown, C.J. and Cheng, J.M. (2014) Electronic Cigarettes: Product Characterisation and Design Considerations. Tobacco Control, 23, ii4-ii10. https://doi.org/10.1136/tobaccocontrol-2013-051476

[3] Flora, J.W., Wilkinson, C.T., Sink, K.M., et al. (2016) Nicotine-Related Impurities in e-Cigarette Cartridges and Refill e-Liquids. Journal of Liquid Chromatography \& Related Technologies, 39, 824-829. https://doi.org/10.1080/10826076.2016.1266500

[4] World Health Organization (2017) Electronic Nicotine Delivery Systems and Electronic Non-Nicotine Delivery Systems (ENDS/ENNDS). Tobacco Free Initiative (TFI). http://www.who.int/tobacco/communications/statements/eletronic-cigarettes-janua ry-2017/en

[5] Goniewicz, M.L., Kuma, T., Gawron, M., Knysak, J., Kosmider, L., et al. (2013) Nicotine Levels in Electronic Cigarettes. Nicotine \& Tobacco Research, 15, 158-166. 
https://doi.org/10.1093/ntr/nts103

[6] National e-Cigarette Survey (NECS) (2016) Prevalence, Pattern and Perception Regarding e-Cigarette and Vape Use among Malaysian Adults. Institute for Public Health, Ministry of Health Malaysia, Kuala Lumpur.

[7] Mohamed Elkalmi, R., Bhagavathul, A.S., Adamu Ya'u, A., et al. (2016) Familiarity, Perception, and Reasons for Electronic-Cigarette Experimentation among the General Public in Malaysia: Preliminary Insight. Journal of Pharmacy and Bioallied Science, 8, 240-247. https://doi.org/10.4103/0975-7406.180768

[8] Department of Health and Human Services, Centers for Disease Control and Prevention, National Center for Chronic Disease Prevention and Health Promotion, Office on Smoking and Health (2014) The Health Consequences of Smoking-50 Years of Progress: A Report of the Surgeon General. Atlanta.

[9] Electronic Cigarette, Wikipedia. https://en.wikipedia.org/wiki/Electronic cigarette

[10] Trehy, M.L., Ye, W., Hadwiger, M.E., et al. (2011) Analysis of Electronic Cigarette Cartridges, Refill Solutions, and Smoke for Nicotine and Nicotine Related Impurities. Journal of Liquid Chromatography \& Related Technologies, 31, 1442-1458. https://doi.org/10.1080/10826076.2011.572213

[11] Goniewicz, M.L., Hajek, P. and McRobbie, H. (2013) Nicotine Content of Electronic Cigarettes, Its Release in Vapour and Its Consistency across Batches: Regulatory Implications. Addiction, 109, 500-507. https://doi.org/10.1111/add.12410

[12] Cameron, J.M., Howell, D.N., White, J.R., et al. (2014) Variable and Potentially Fatal Amounts of Nicotine in e-Cigarette Nicotine Solutions. Tobacco Control, 23, 77-78. https://doi.org/10.1136/tobaccocontrol-2012-050604

[13] Goniewicz, M.L., Gupta, R., Lee, Y.H., et al. (2015) Nicotine Levels in Electronic Cigarette Refill Solutions: A Comparative Analysis of Products from the US, Korea, and Poland. The International Journal on Drug Policy, 26, 583-588. https://doi.org/10.1016/j.drugpo.2015.01.020

[14] AEMSA (2017) E-Liquid Manufacturing Standards 2017. Version 2.3.2, 4.

[15] Department of Health and Human Services (1999) Notice Regarding Requirement for Annual Submission of the Quantity of Nicotine Contained in Smokeless Tobacco Products Manufactured, Imported, or Packaged in the United States. Federal Register, 64, 14086-14096.

[16] Farsalinos, K.E., Romagna, G., Tsiapras, D., et al. (2013) Evaluating Nicotine Levels Selection and Patterns of Electronic Cigarette Use in a Group of "Vapers" Who Had Achieved Complete Substitution of Smoking. Substance Abuse, 7, 139-146. https://doi.org/10.4137/SART.S12756

[17] National Institute for Occupational Safety and Health (1998) NIOSH Manual of Analytical Methods (NMAM). Fourth Edition, Issue 1, Dated 15 January 1998. Nicotine: Method 2551.

[18] Davis, B., Dang, M., Kim, J. and Talbot, P. (2014) Nicotine Concentrations in Electronic Cigarette Refill and Do-It-Yourself Fluid. Nicotine \& Tobacco Research Advance, 17, 134-141. https://doi.org/10.1093/ntr/ntu080

[19] Etter, J.F., Zäther, E. and Svensson, S. (2013) Analysis of Refill Liquids for Electronic Cigarettes. Addiction, 108, 1671-1679. https://doi.org/10.1111/add.12235

[20] Joseph, G.L., Hang, T., Stephen, B.S., et al. (2015) Chemical Composition and Evaluation of Nicotine, Tobacco Alkaloids, $\mathrm{pH}$ and Selected Flavors in E-Cigarette Cartridges and Refill Solutions. Nicotine \& Tobacco Research, 17, 1270-1278. https://doi.org/10.1093/ntr/ntu279 
[21] Tomar, S.L. and Henningfield, J.E. (1997) Review of the Evidence That pH Is a Determinant of Nicotine Dosage from Oral Use of Smokeless Tobacco. Tobacco Control, 6, 219-225. https://doi.org/10.1136/tc.6.3.219

[22] Williams, M. and Tyalbot, P. (2011) Variability among Electronic Cigarettes in the Pressure Drop, Airflow Rate, and Aerosol Production. Nicotine \& Tobacco Research, 13, 1276-1283. https://doi.org/10.1093/ntr/ntr164

[23] Ingebrethsen, B.J., Cole, S.K. and Aldermen, S.L. (2012) Electronic Cigarette Aerosol Particle Size Distribution Measurements. Inhalation Toxicology, 24, 976-984. https://doi.org/10.3109/08958378.2012.744781

[24] Herrington, J.S. and Myers, C. (2015) Electronic Cigarette Solutions and Resultant Aerosol Profiles. Journal of Chromatography A, 1418, 192-199.

https://doi.org/10.1016/j.chroma.2015.09.034

[25] World Health Organization (2010) Gender, Woman and the Tobacco Epidemic: Addiction to Tobacco. Geneva, 137-149.

[26] Mishra, A., Chaturvedi, P., Datta, S., et al. (2015) Harmful Effects of Nicotine. Indian Journal of Medical and Paediatric Oncology, 36, 24-31.

https://doi.org/10.4103/0971-5851.151771 